\title{
Sublethal Oxygen-Glucose Deprivation Alters Hippocampal Neuronal AMPA Receptor Expression and Vulnerability to Kainate-Induced Death
}

\author{
Howard S. Ying, ${ }^{1}$ Jochen H. Weishaupt, ${ }^{2}$ Margaret Grabb, ${ }^{1}$ Lorella M. T. Canzoniero, ${ }^{1}$ Stefano L. Sensi, ${ }^{1}$ \\ Christian T. Sheline, ${ }^{1}$ Hannah Monyer, ${ }^{2}$ and Dennis W. Choi ${ }^{1}$ \\ ${ }^{1}$ Center for the Study of Nervous System Injury and Department of Neurology, Washington University School of Medicine, \\ St. Louis, Missouri 63110, and ²Center for Molecular Biology (ZMBH), University of Heidelberg, 69120 Heidelberg, \\ Germany
}

Recent studies have suggested that rats subjected to transient global brain ischemia develop depressed expression of GluR-B in CA1 hippocampal neurons. The present study was performed to determine whether a similar change in AMPA receptor expression could be triggered in vitro by sublethal oxygen-glucose deprivation in rat hippocampal neuronal cultures. mRNA was extracted from individual hippocampal neurons via patch electrodes and amplified by RT-PCR 24-48 hr after sublethal oxygen-glucose deprivation. Compared with controls, insulted neurons expressed increased levels of GluR-D flop. As an indication that this change in receptor expression was functionally significant, insulted cultures exhibited increased AMPA- or kainate-induced ${ }^{45} \mathrm{Ca}^{2+}$ accumulation sensitive to Joro spider toxin and increased vulnerability to kainate-induced death. These data support the hypothesis that exposure to ischemia may enhance subsequent hippocampal neuronal vulnerability to AMPA receptor-mediated excitotoxicity by modifying the relative expression of AMPA receptor subunits in a manner that promotes $\mathrm{Ca}^{2+}$ permeability.

Key words: glutamate receptor regulation; GluR-D; single cell RT-PCR; calcium accumulation; ischemia; neuronal vulnerability
Considerable evidence suggests that the excitotoxic overactivation of glutamate receptors contributes to neuronal death after ischemic insults (Meldrum, 1985; Choi and Rothman, 1990). Although initial attention focused on the prominent role of NMDA receptors in mediating focal ischemic injury (Albers et al., 1989; Buchan, 1990), subsequent studies indicated that AMPA/kainate antagonists were better than NMDA antagonists in preventing the selective death of hippocampal CA1 neurons after transient global ischemia (Sheardown et al., 1990; Buchan et al., 1991a).

The prominence of NMDA receptors in focal ischemic injury seems well explained by the systematic link between these receptors and calcium-permeable channels (Choi, 1985, 1992; MacDermott et al., 1986). On the other hand, the prominence of AMPA/ kainate receptors in selective hippocampal CA1 neuronal death after global ischemia is less easily explained. One possibility is that AMPA/kainate receptor-mediated toxicity is unmasked by a relative downmodulation of NMDA receptors, which is induced by lowered pH (Giffard et al., 1990; Tang et al., 1990; Tombaugh and Sapolsky, 1990), oxidative stress (Aizenman et al., 1989), or increased extracellular zinc (Peters et al., 1987; Westbrook and Mayer, 1987). In addition, activation of AMPA/kainate receptors can potentiate zinc-induced neuronal death (Weiss et al., 1991), and recent experiments using a zinc chelator have suggested that toxic zinc entry may be a critical component of many types of

\footnotetext{
Received June 6, 1997; revised Sept. 3, 1997; accepted Oct. 7, 1997.

This work was supported by Deutsch Forschungsgemeinschaft Grant MO 432/3-1 (H.M.) and National Institutes of Health Grant NS32636 (D.W.C.).

Correspondence should be addressed to Dr. Dennis Choi, Department of Neurology, Washington University School of Medicine, 660 S. Euclid Avenue, St. Louis, MO 63110.

Copyright (C) 1997 Society for Neuroscience $\quad 0270-6474 / 97 / 179536-09 \$ 05.00 / 0$
}

selective neuronal death after transient global ischemia (Koh et al., 1996).

An intriguing additional factor was raised by the finding that AMPA receptor subunit GluR-B (or GluR2) mRNA is preferentially decreased in CA1 neurons after transient global ischemia but before cell death (Pellegrini-Giampietro et al., 1992). Because inclusion of the GluR-B subunit conveys calcium impermeability to heteromeric AMPA receptor-gated channels (Hume et al., 1991; Burnashev et al., 1992; for review, see Burnashev, 1996), it is possible that this reduction in GluR-B expression, if translated into new AMPA receptors lacking the GluR-B subunit, might facilitate toxic AMPA receptor-mediated calcium or zinc (Koh et al., 1996; Yin et al., 1996) entry into CA1 neurons.

The present study was performed to test two implications of this novel hypothesis. The first implication is that oxygen-glucose deprivation per se is sufficient to trigger a reduction in GluR-B expression relative to other AMPA receptor subunits in hippocampal cell cultures lacking the more complex systemic changes induced by ischemia in vivo. The second implication is that this change in fact translates into an enhancement of AMPA receptor-gated calcium entry in hippocampal neurons (Gorter et al., 1997) and neuronal death.

A preliminary account of this work has been published previously (Ying et al., 1996).

\section{MATERIALS AND METHODS}

Cell culture. Rat hippocampal cell cultures were prepared from Sprague Dawley rats (Simonsen Laboratories) at $17 \mathrm{~d}$ gestation using methods modified from those described previously (Dichter, 1978; Rose et al., 1993). For glial cultures, hippocampi were dissociated and plated in 24-well plates at a density of 10-12 hippocampi per plate in minimal essential medium (MEM; Earle's salts, supplied bicarbonate-free) supplemented with $10 \%$ horse serum, $10 \%$ fetal bovine serum, $21 \mathrm{~mm}$ glucose, and $26.5 \mathrm{~mm}$ bicarbonate. The glial plates were then maintained 
for 2-4 weeks in a humidified incubator with $5 \% \mathrm{CO}_{2}$ at $37^{\circ} \mathrm{C}$. Nonastrocytic cells were removed by exposing the cultures to air for $5 \mathrm{sec}$ and bathing the remaining cells with fresh media after $14 \mathrm{~d}$ in vitro (DIV). Animals were handled in accordance with a protocol approved by our institutional animal care committee. All efforts were made to minimize animal suffering and the number of animals used.

For mixed neuronal-glial cultures, dissociated hippocampal cells obtained from fetal rats [embryonic day 17 (E17)] were plated on $35 \mathrm{~mm}$ glass-bottom dishes coated with poly-D-lysine $(25 \mu \mathrm{g} / \mathrm{ml})$ and laminin $(1 \mu \mathrm{g} / \mathrm{ml})$ at a density of 2.0-2.5 hippocampi $/ \mathrm{ml}$ in MEM supplemented with 5\% horse serum, $5 \%$ fetal bovine serum, $21 \mathrm{~mm}$ glucose, and $26 \mathrm{~mm}$ bicarbonate. Alternatively, cells grown in 24-well plates were plated onto a preexisting glial monolayer at a density of 24-30 hippocampi per plate. Proliferation of non-neuronal cells was halted by adding $10 \mu \mathrm{M}$ cytosine arabinoside at DIV $4-7$, depending on the plating conditions. At the same time, cultures were shifted into a growth medium identical to the plating media but containing $10 \%$ horse serum and lacking fetal serum. Mixed neuronal-glial cultures were maintained for up to 4 weeks in a humidified incubator with $5 \% \mathrm{CO}_{2}$ at $37^{\circ} \mathrm{C}$ by exchanging half of the bathing medium with growth medium twice per week during the first 2 weeks and with media stock lacking serum twice per week for the second 2 weeks.

Oxygen-glucose deprivation. Combined oxygen-glucose deprivation (ischemia) experiments are performed generally as described previously (Goldberg and Choi, 1993) in a chamber (Forma Scientific) containing an anaerobic gas mixture $\left(\mathrm{N}_{2} 85 \%, \mathrm{H}_{2} 10 \%, \mathrm{CO}_{2} 5 \%\right)$. The culture medium, media stock, is replaced with deoxygenated glucose-free balanced salt solution (concentrations in $\mathrm{mM}$ ): $\mathrm{NaCl} 116, \mathrm{KCl} 5.4, \mathrm{MgSO}_{4} \cdot 7 \mathrm{H}_{2} \mathrm{O} 0.8$, $\left.\mathrm{NaH}_{2} \mathrm{PO}_{4} \cdot \mathrm{H}_{2} \mathrm{O} 1.0, \mathrm{CaCl}_{2} 1.8, \mathrm{NaHCO}_{3} 26\right)$ by three large washes (dilution $\sim 2000$ ). During the deprivation procedure, cells are placed in a humidified, $37^{\circ} \mathrm{C}$ incubator within the chamber. Deprivation is terminated by replacing the exposure medium with media stock. Cultures were assayed for AMPA receptor mRNA expression, AMPA receptoractivated $\mathrm{Ca}^{2+}$ influx, or AMPA receptor-mediated cell death $20-48 \mathrm{hr}$ after the deprivation period.

Excitotoxin exposure. For excitotoxicity experiments, mixed hippocampal cultures (DIV 18-21) were exposed to NMDA for $5 \mathrm{~min}$ in HEPES control salt solution (HCSS) $(120 \mathrm{~mm} \mathrm{NaCl}, 4.5 \mathrm{~mm} \mathrm{KCl}, 0.8 \mathrm{~mm}$ $\mathrm{MgCl}_{2}, 1.8 \mathrm{mM} \mathrm{CaCl}_{2}, 20 \mathrm{~mm}$ HEPES, and $15 \mathrm{~mm}$ glucose, $\mathrm{pH} 7.4$ ). Exposures were terminated by washing back into media stock. Cultures were exposed to AMPA or kainate for $24 \mathrm{hr}$ in MEM supplemented with $21 \mathrm{~mm}$ glucose, $26 \mathrm{~mm}$ bicarbonate, and $1 \mu \mathrm{M}(5 \mathrm{R}, 10 \mathrm{~S})-(+)-5$-methyl10,11-dihydro-5 H-dibenzo[a,d]cyclohepten-5,10-imine hydrogen maleate (MK-801) (to block secondary activation of NMDA receptors).

Injury assessment. $24 \mathrm{hr}$ after injury onset, cell death was estimated by measuring release of the cytosolic enzyme lactate dehydrogenase (LDH) into the bathing medium, subtracting LDH activity found in sham-washed cultures (presumably reflecting spontaneous cell death or residual serum $\mathrm{LDH}$ ), and scaling to the $\mathrm{LDH}$ activity released by $300 \mu \mathrm{M}$ NMDA, which produces complete and selective neuronal death (Koh and Choi, 1987). Afterward, the values obtained by LDH assay were confirmed by counting the proportion of cells stained by the vital dye trypan blue $(0.01 \%)$. Control experiments indicated that sublethal oxygen-glucose deprivation did not alter total neuronal LDH levels or total cell numbers in the cultures.

Metabolic labeling. Cultures were washed into DMEM lacking methionine and supplemented with $21 \mathrm{~mm}$ glucose and $26.5 \mathrm{~mm}$ bicarbonate. Then, $\left[{ }^{35} \mathrm{~S}\right]$ methionine $(>800 \mathrm{Ci} / \mathrm{mmol}$; Amersham, Arlington Heights, IL) was added to the culture medium at a final concentration of 0.5 $\mu \mathrm{Ci} / \mathrm{ml}$ for $1 \mathrm{hr}$ at $37^{\circ} \mathrm{C}$ in a humidified $5 \% \mathrm{CO}_{2}$ incubator. Cultures were then washed with ice-cold PBS and lysed in modified RIPA buffer (150 $\mathrm{mm} \mathrm{NaCl}, 10 \mathrm{~mm} \mathrm{Na}_{2} \mathrm{HPO}_{4}$, pH 7.2, $1 \mathrm{~mm}$ dithiothreitol, $1 \%$ deoxycholate, $1 \%$ Nonidet P-40, $0.5 \%$ SDS). Nucleic acids were removed from the extract by centrifugation at $16,000 \times g$ for $30 \mathrm{~min}$, and protein concentration was determined by micro-BCA assay (Pierce, Rockford, IL). Protein $(20 \mu \mathrm{g})$ from each culture was precipitated onto glass microfiber filters (Whatman GF/A, Whatman, Maidstone, UK) using $10 \%$ trichloroacetic acid and bovine serum albumin as a carrier protein Filters were then washed with $100 \%$ ethanol, air-dried for $30 \mathrm{~min}$, transferred to scintillation vials, and bathed in nonaqueous scintillant. Radioactivity was detected in a liquid scintillation counter (Packard 1600, Packard, Meridian, CT). Counts for each experiment were scaled to control levels $(100 \%)$ and then pooled.

${ }^{45} \mathrm{Ca}^{2+}$ accumulation. Cultures were incubated in HCSS lacking added cold calcium with the desired drugs and ${ }^{45} \mathrm{Ca}^{2+}(2 \mu \mathrm{Ci} / \mathrm{ml}$,
DuPont NEN, Wilmington, DE) $(\sim 2 \mu \mathrm{M})$, generally as described previously (Hartley et al., 1993). After 5 min, the stimulus solution was washed out with three washes of ice-cold quench solution $\left[\mathrm{HCSS}\left(-\mathrm{Ca}^{2+}\right)\right]$ containing $2 \mathrm{mM} \mathrm{LaCl}_{3}$ to remove residual extracellular ${ }^{45} \mathrm{Ca}^{2+}$ (Hellman, 1978), and the culture vessel was placed on ice. Twenty minutes later, the quench solution was aspirated, and the cells were lysed by the addition of $100 \mu \mathrm{l}$ of hot $0.2 \%$ SDS solution. The lysate was then transferred to scintillation vials containing aqueous scintillant and counted using a liquid scintillation counter (Packard 1600).

Intracellular free $\mathrm{Ca}^{2+}$ determination. Neuronal intracellular free $\mathrm{Ca}^{2+}\left(\left[\mathrm{Ca}^{2+}\right]_{\mathrm{i}}\right)$ was measured using fura-2 fluorescence videomicroscopy (Grynkiewicz et al., 1985). Hippocampal cultures for $\left[\mathrm{Ca}^{2+}\right]_{\mathrm{i}} \mathrm{im}-$ aging experiments were prepared on glass-bottom $35 \mathrm{~mm}$ dishes as described above, and experiments were performed between DIV 18 and 21. Twenty-four hours after sublethal oxygen-glucose deprivation, cells were loaded with $5 \mu \mathrm{M}$ fura-2 AM (acetoxymethyl ester) plus $0.1 \%$ pluronic F-127 for $30 \mathrm{~min}$ at room temperature, washed, and incubated for an additional $30 \mathrm{~min}$ in HBSS. Experiments were performed at room temperature on the stage of a Nikon Diaphot inverted microscope equipped with a $75 \mathrm{~W}$ Xenon lamp and a Nikon $40 \times, 1.3$ numerical aperture epifluorescence oil immersion objective under continuous perfusion (perfusion rate $2 \mathrm{ml} / \mathrm{min}$ ). Fura-2 (excitation $\lambda=340,380 \mathrm{~nm}$; emission $\lambda=510 \mathrm{~nm}$ ) ratio images (in the plane of the neuronal cell bodies, contamination from underlying glia was minimal) were acquired with a CCD camera (Quantex) and digitized $(256 \times 512$ pixels $)$ using Image-1 (Universal Imaging). Calibrated $\left[\mathrm{Ca}^{2+}\right]_{\mathrm{i}}$ values were obtained using the ratio method of Grynkiewicz et al. (1985) by determining $F_{\min }$ and $F_{\text {max }}$ in situ using EGTA $(10 \mathrm{mM})$ with $0 \mathrm{Ca}^{2+}$ buffer and ionomycin $(10 \mu \mathrm{M})$ for $F_{\min }$ and $10 \mathrm{mM} \mathrm{Ca}^{2+}$ with ionomycin $(10 \mu \mathrm{M})$ for $F_{\max }$. A $K_{\mathrm{d}}$ value of $225 \mathrm{nM} \mathrm{Ca}^{2+}$ was used for fura-2.

Tissue level RT-PCR. RNA was extracted using the Ultraspec RNA reagent (Biotecx, Houston, TX). Briefly, cultures were washed with ice-cold RNase-free PBS and lysed in Ultraspec RNA $\left(0.1 \mathrm{ml} / 2 \times 10^{5}\right.$ cells). Chloroform was added to resolve aqueous and organic compartments, and the RNA was precipitated in isopropanol and washed in $75 \%$ ethanol. Typically 15-20 $\mu \mathrm{g}$ RNA could be obtained from $10^{6}$ cells, and $1 \mu \mathrm{g}$ was used for RT-PCR. RT was performed in a $30 \mu \mathrm{l}$ volume, and 2 $\mu \mathrm{l}$ was used for PCR as described below.

Single cell RT-PCR. Single cell mRNA was harvested through the patch pipette, reverse-transcribed, and amplified (Eberwine et al., 1992) with hemi-nested degenerate primers that equally amplified all four AMPA receptor subunits as described previously (Lambolez et al., 1992; Jonas et al., 1994). Controls for possible contamination artifacts were performed at the level of harvesting as well as for each PCR reaction (Monyer and Jonas, 1995). Control experiments showed that repetitive PCR on the same material did not affect the rank order of the abundances of the different subunits, although continued cycling of a reaction with several micrograms of product could cause a decrease in the range of abundances. For most cells, after the first PCR, a faint ethidium bromide-stained band was observed, and the second PCR was halted after 25 cycles. Final PCR products were purified, dot-blotted, and probed using radiolabeled oligonucleotides specific for each subunit (Keinanen et al., 1990) as described previously (Flint et al., 1997). By analysis of inside dot volume, linear standard curves were obtained between 0.4 and $100 \mathrm{ng}$ cDNA/dot, $r^{2}>0.96$. All samples were blotted on a separate membrane for each subunit, because stripping and reprobing the same membrane resulted in $\leq 10 \%$ variability. Probe crosshybridization for most experiments was assayed by blotting each of the AMPA receptor subunits onto each membrane and varied from 0.01 to $2.3 \%$ for each probe (data not shown). The ability to reproducibly amplify single cell mRNA was demonstrated by taking the reverse transcription product for a cell, separating it into two parts, and amplifying and processing each part separately. The results for 13 cells varied, with an average difference in relative abundance of $1.2 \pm 0.3$ to $2.5 \pm$ $1.1 \%$ (Fig. 1).

$R / G$-site editing and flip/flop ratio analysis. PCR amplification of the first round PCR products was performed using 5'-TCGTACCACC ATTTG(TC)TTTTCA-3' as a $3^{\prime}$ primer and $5^{\prime}$-GCGAATTCACAC AAAGTAGTGAATCAACT- $3^{\prime}$ for GluR-B amplification or $5^{\prime}$-GCGA ATTCCTGAGGATGGGAAGGAAGG-3' for GluR-D amplification. The PCR fragments were then cycle-sequenced, and arginine/glycine $(\mathrm{R} / \mathrm{G})$ site editing efficiency was determined as described previously (Maas et al., 1996, Melcher et al., 1996). Flip/flop ratios were calculated similarly, using the means of positions 16, 33, and 46 (GluR-B) or 16, 33, and 38 (GluR-D) in exons 14 (flop) and 15 (flip). PCR-amplifications 


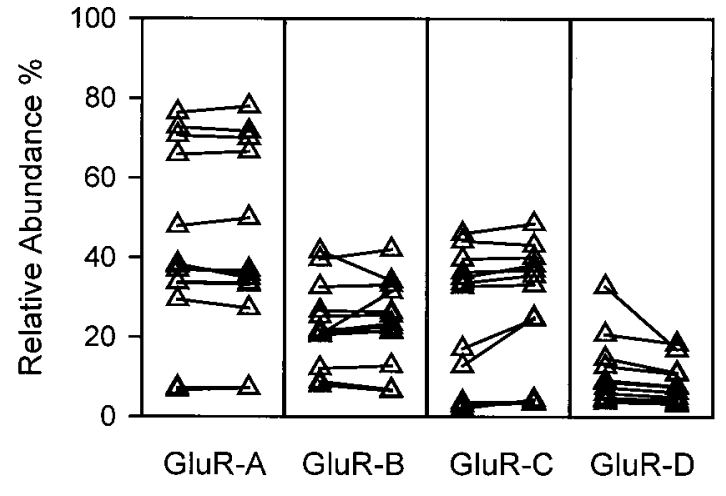

Avg. Difference $\quad 1.2 \pm 0.3 \quad 2.3 \pm 0.9 \quad 2.5 \pm 1.0 \quad 2.5 \pm 1.1$

Figure 1. Amplification and detection of AMPA receptors by single cell RT-PCR is reproducible. Cytoplasmic contents from 13 cells were aspirated via patch electrode and reverse-transcribed as described in Materials and Methods. Then, half $(5 \mu \mathrm{l})$ of each product was aliquoted into a fresh PCR tube and amplified and detected separately. $\mathbf{\Delta}$ indicate relative mRNA abundance for each subunit; left, as determined in the original tubes; right, as determined in the second aliquots. A line connects samples drawn from the same cell. Average difference refers to the mean shift in relative abundance between the original and aliquoted samples for that subunit.

using mixed flip or flop plasmids as templates revealed a close correspondence between calculated and experimental ratios in the range of $10-90 \%$.

\section{RESULTS}

\section{Oxygen-glucose deprivation conditioning}

Rat mixed hippocampal cell cultures (DIV 18-22) containing both astrocytes and neurons were subjected to a sublethal conditioning insult that consisted of combined oxygen and glucose deprivation either for 20-30 min (cultures in 24-well vessels) or for 30-60 min (cultures in $35 \mathrm{~mm}$ dishes). Twenty-four hours after the deprivation period, cultures exhibited only $2-5 \%$ neuronal death, which remained constant for at least $72 \mathrm{hr}$ and was similar to that seen in sham-washed cultures.

\section{Changes in global protein synthesis}

Previous studies have indicated that ischemic insults can suppress protein synthesis well before cell death ensues (Kleihues and Hossmann, 1971; Kirino and Sano, 1984; Thilmann et al., 1986). To assess changes in global protein synthesis induced by the above conditioning insult, cultures were metabolically labeled with ${ }^{35} \mathrm{~S}$-methionine for $1 \mathrm{hr}$ epochs. After the conditioning oxygen-glucose deprivation, protein synthesis decreased to $58 \%$ of control at $4 \mathrm{hr}$ and then rebounded to $150 \%$ of control at $24 \mathrm{hr}$ (Fig. 2). Cultures exposed to sham wash, a mild insult per se, showed a trend toward slight protein synthesis reduction at $4 \mathrm{hr}$, with rebound recovery at $24 \mathrm{hr}$. As a positive control, sister cultures were treated with $0.5 \mu \mathrm{g} / \mathrm{ml}$ cycloheximide for $24 \mathrm{hr}$ before metabolic labeling, which reduced protein synthesis to $23.9 \pm 0.5 \%$ of control.

\section{Tissue level AMPA receptor mRNA expression}

Reverse transcription and PCR (40 cycles) on RNA extracted from 24-well plates were performed using hemi-nested degenerate oligonucleotide primers to detect the four major AMPA receptor subunits. As shown in Table 1, no significant change in AMPA receptor expression was found after the conditioning insult. Cultures expressed $\sim 45 \%$ GluR-A, 25\% GluR-B, 20\%

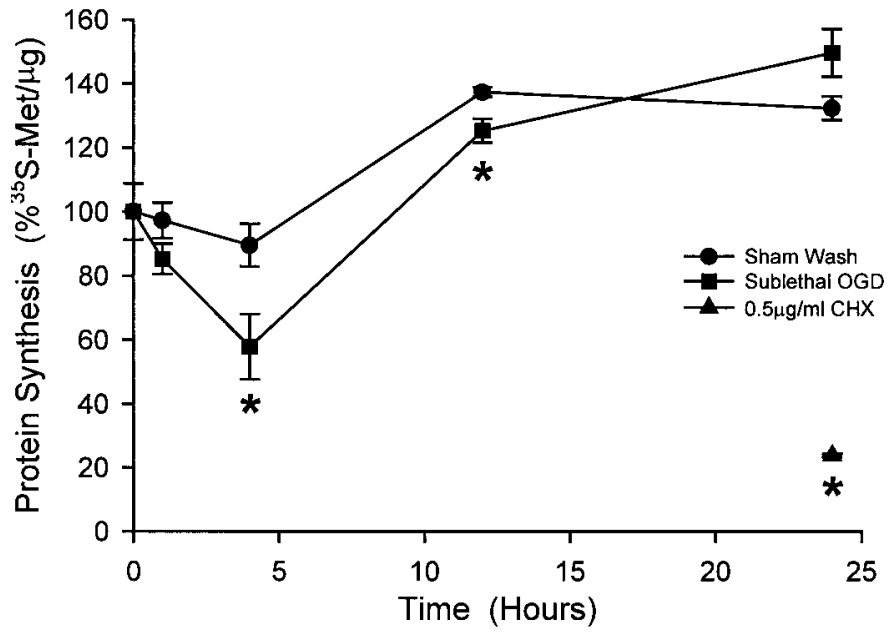

Figure 2. Protein synthesis inhibition after sublethal oxygen-glucose deprivation (OGD) is mild and transient. Sister cultures were labeled with $\left[{ }^{35} \mathrm{~S}\right]$ methionine for $1 \mathrm{hr}$ epochs either before $(0 \mathrm{hr})$ or at the indicated times after $(\bullet)$ sham wash, (ם) 30 min sublethal OGD, or $(\boldsymbol{\Delta})$ continuous application of $0.5 \mu \mathrm{g} / \mathrm{ml}$ cycloheximide (mean $\pm \mathrm{SEM} ; n=8$ cultures). Asterisks indicate difference from sham wash at corresponding time point; $p<0.05$ using two-tailed Student's $t$ test.

Table 1. Sublethal oxygen-glucose deprivation (OGD) does not affect overall GluR-B mRNA abundance in rat hippocampal cultures containing both neurons and glia

\begin{tabular}{llll} 
AMPA receptor & Sham wash & OGD & $p$ \\
\hline GluR-A & $47.5 \pm 7.2$ & $41.6 \pm 9.4$ & 0.623 \\
GluR-B & $25.9 \pm 5.9$ & $18.9 \pm 6.5$ & 0.434 \\
GluR-C & $17.2 \pm 5.5$ & $25.2 \pm 3.7$ & 0.240 \\
GluR-D & $9.4 \pm 1.9$ & $14.3 \pm 4.5$ & 0.330
\end{tabular}

Sister cultures were exposed to sublethal oxygen-glucose deprivation (20-30 min), allowed to recover for $24 \mathrm{hr}$, and extracted for RNA. RT-PCR products were quantitated using a phosphorimager, and the relative abundance of each transcript was expressed as percentage of total for each culture (mean \pm SEM; $n=12$ measurements; $p$ was calculated using two-tailed Student's $t$ test).

GluR-C, and 10\% GluR-D 24 hr after sham wash or sublethal oxygen-glucose deprivation. Because the glutamine/arginine $(\mathrm{Q} / \mathrm{R})$ site editing state of GluR-B controls the calcium permeability of AMPA receptor complexes, we then tested the effect of oxygen-glucose deprivation on GluR mRNA expression. PCRamplified cDNA from hippocampal cultures containing both neurons and glia was probed for GluR-B Q/R site editing by primer extension assay (Egebjerg et al., 1994; Puchalski et al., 1994). This experiment demonstrated that $>97 \%$ GluR-B was edited in both sham-washed and conditioned cultures (data not shown).

Inability to detect changes in neuronal AMPA receptor expression in this tissue level experiment is not surprising, because glial cells also express AMPA receptors (Holzwarth et al., 1994) and comprise $70-90 \%$ of cells in rat mixed hippocampal cultures. Therefore, we needed to assay AMPA receptor mRNA in neurons alone. Although it is possible to culture neurons with few glial cells $(<5 \%)$, this small population of glial cells consists primarily of large, type 2 astrocytes that could still obscure changes in neuronal AMPA receptor expression. In addition, rat hippocampal neuronal-enriched cultures require use of glutamate receptor antagonists in the culture medium after DIV 10 to suppress spontaneous excitotoxic cell death, a perturbation we considered unacceptable in the context of the present experiments. 


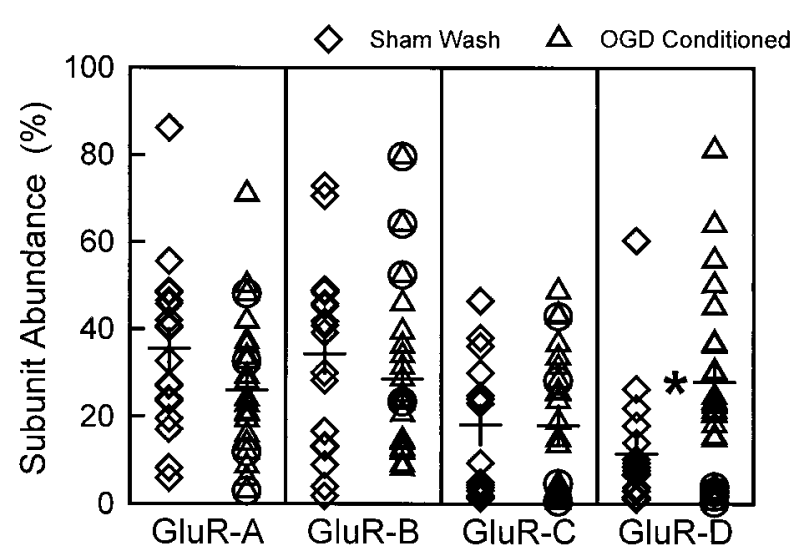

Figure 3. Sublethal oxygen-glucose deprivation (OGD) increases GluR-D mRNA relative abundance in cultured hippocampal neurons. Relative mRNA abundance for each subunit in a single cell for shamwashed controls ( $; n=18$ cells) or for OGD conditioned cells $(\mathbf{\Delta} ; n=$ 23 cells) show large variance in each group. Cross-hairs are placed at the mean for each experimental group, and circles were drawn around four cells that appeared atypical. Asterisk indicates difference from corresponding sham wash control at $p=0.006$, using two-tailed Student's $t$ test.

Another strategy to harvest pure neuronal RNA would be to culture neurons on a glial monolayer and dissociate neurons from glia by light trypsinization and centrifugation before extracting "neuronal" RNA. We found this method unsatisfactory because glial fibrillary acidic protein mRNA was easily detected by RT-PCR in every attempt to harvest pure neuronal RNA by this method (data not shown). Thus, we turned to the method of single cell RT-PCR, which allows the direct sampling of RNA from individual neurons (Eberwine et al., 1992; Lambolez et al., 1992; Jonas et al., 1994; Geiger et al., 1995).

\section{Single cell AMPA receptor mRNA expression}

Neurons from cultures grown in $35 \mathrm{~mm}$ dishes were either shamwashed or conditioned with sublethal oxygen-glucose deprivation and then randomly selected for harvesting of cellular RNA through a patch pipette. Reverse transcription and two rounds of PCR (40 and 35 cycles) were performed using hemi-nested degenerate oligonucleotide primers to detect the four major AMPA receptor subunits. PCR products were probed with subunitspecific oligonucleotides and quantitated using a phosphorimager. After conditioning oxygen-glucose deprivation, GluR-D mRNA relative abundance was increased. Average percentage of total AMPA receptor abundance \pm SEM for 41 cells was as follows (sham washed vs insulted): GluR-A, $35.5 \pm 4.5$ versus $26.0 \pm 3.5$ ( $p=0.098$ using two-tailed Student's $t$ test); GluR-B, $34.4 \pm 5.0$ versus $28.6 \pm 3.8(p=0.352)$; GluR-C, $18.2 \pm 3.8$ versus $18.0 \pm 3.3$ $(p=0.968)$; and GluR-D, $11.5 \pm 3.3$ versus $28.0 \pm 4.3(p=0.006)$ (Fig. 3). Thus, conditioning oxygen-glucose deprivation increased the abundance of GluR-D relative to GluR-A [GluR-A - GluR-D (sham washed vs insulted): $21.3 \pm 6.7$ versus $-1.95 \pm 6.56(p=$ 0.019 using two-tailed Student's $t$ test)] and to GluR-B [GluR-B GluR-D: $20.5 \pm 6.8$ vs $0.621 \pm 6.430(p=0.041)]$ but not to GluR-C (GluR-C - GluR-D: $3.96 \pm 5.66$ vs $-9.97 \pm 6.56(p=$ 0.124)]. Flip/flop analysis comparing sham-washed controls with oxygen-glucose deprivation conditioned cells demonstrated that the increase in GluR-D was caused by an increase in GluR-D flop (from $8.17 \% \pm 1.32$ to $20.0 \% \pm 3.6 ; p=0.008$ using two-tailed Student's $t$ test) (Fig. 4). There was a nonsignificant trend ( $p=$ 0.085 ) toward a concomitant increase in GluR-D flip.

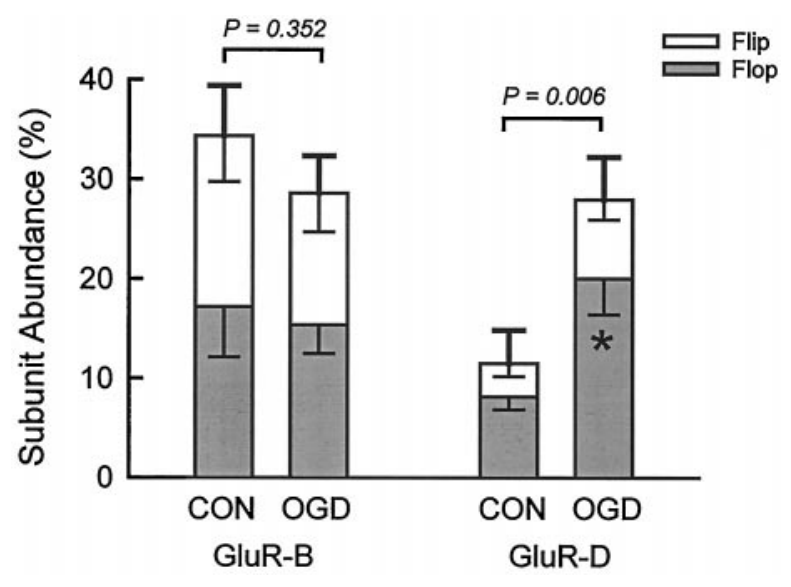

Figure 4. Flip/flop analysis comparing sham-washed controls with oxygen-glucose deprivation (OGD) conditioned cells demonstrated that the increase in GluR-D was caused by an increase in GluR-D flop (bars show mean \pm SEM abundance for each flip or flop subtype; $n=18-23$ ). Asterisk indicates difference from corresponding control flop subunit at $p<0.05$, using two-tailed Student's $t$ test.

Table 2. Amount of edited GluR-D increases after oxygen-glucose deprivation (OGD) conditioning

\begin{tabular}{lccc} 
AMPA receptor & Sham wash & OGD & $p$ \\
\hline GluR-B (R) & $13.2 \pm 2.2$ & $8.84 \pm 1.99$ & 0.310 \\
GluR-B (G) & $21.1 \pm 3.5$ & $19.76 \pm 3.66$ & 0.813 \\
GluR-B \% R/G edited & $61.5 \pm 10.2$ & $69.1 \pm 6.2$ & 0.509 \\
GluR-D (R) & $2.7 \pm 0.4$ & $4.23 \pm 1.45$ & 0.437 \\
GluR-D (G) & $8.9 \pm 1.3$ & $23.7 \pm 3.8^{a}$ & 0.002 \\
GluR-D \% R/G edited & $76.9 \pm 11.0$ & $84.9 \pm 4.3$ & 0.465
\end{tabular}

Cells after sublethal oxygen-glucose deprivation were compared with sham-washed controls. R/G editing analysis of GluR-B showed no change in GluR-B (R) and GluR-B (G) after sublethal oxygen-glucose deprivation. GluR-D, however, showed an increase in GluR-D (G) but no change in GluR-D (R) after sublethal oxygenglucose deprivation (mean $\pm \mathrm{SEM} ; n=18-23$ cells).

${ }^{a}$ Difference from sham wash level; $p<0.05$ using two-tailed Student's $t$ test.

In exon 13 of GluR-B, GluR-C, and GluR-D, a posttranscriptional codon switch from AGA to GGA (R/G site editing) is developmentally regulated and causes faster recovery rates from desensitization (Lomeli et al., 1994; Seeburg, 1996). Increased $\mathrm{R} / \mathrm{G}$ editing might cause increased calcium entry during repetitive or prolonged stimulation. Although conditioning increased the relative abundance of GluR-D $(G)$, it did not produce changes in the ratio of GluR-D $(R)$ to GluR-D $(G)$, or the ratio of GluR-B(R) to GluR-B(G), which would be suggestive of altered $\mathrm{R} / \mathrm{G}$ site editing (Table 2 ).

\section{${ }^{45} \mathrm{Ca}^{2+}$ accumulation and $\Delta\left[\mathrm{Ca}^{2+}\right]_{\mathrm{i}}$}

Cultures grown in 24-well culture vessels were either sham washed or conditioned with sublethal oxygen-glucose deprivation, and then exposed to $300 \mu \mathrm{M}$ AMPA or $500 \mu \mathrm{M}$ kainate in the presence of $10 \mu \mathrm{M}$ MK-801 (to block secondary activation of NMDA receptors) and ${ }^{45} \mathrm{Ca}^{2+}(2 \mu \mathrm{Ci} / \mathrm{ml})$ for 5 min (Hartley et al., 1993). Conditioned cultures showed an increase in kainatestimulated ${ }^{45} \mathrm{Ca}^{2+}$ accumulation as well as an increase in AMPAstimulated ${ }^{45} \mathrm{Ca}^{2+}$ accumulation, which was completely blocked by the competitive AMPA/kainate antagonist 1,2,3,4-tetrahydro6-nitro-2,3-dioxo-benzo[f]quinoxaline-7-sulfonamide (NBQX). 


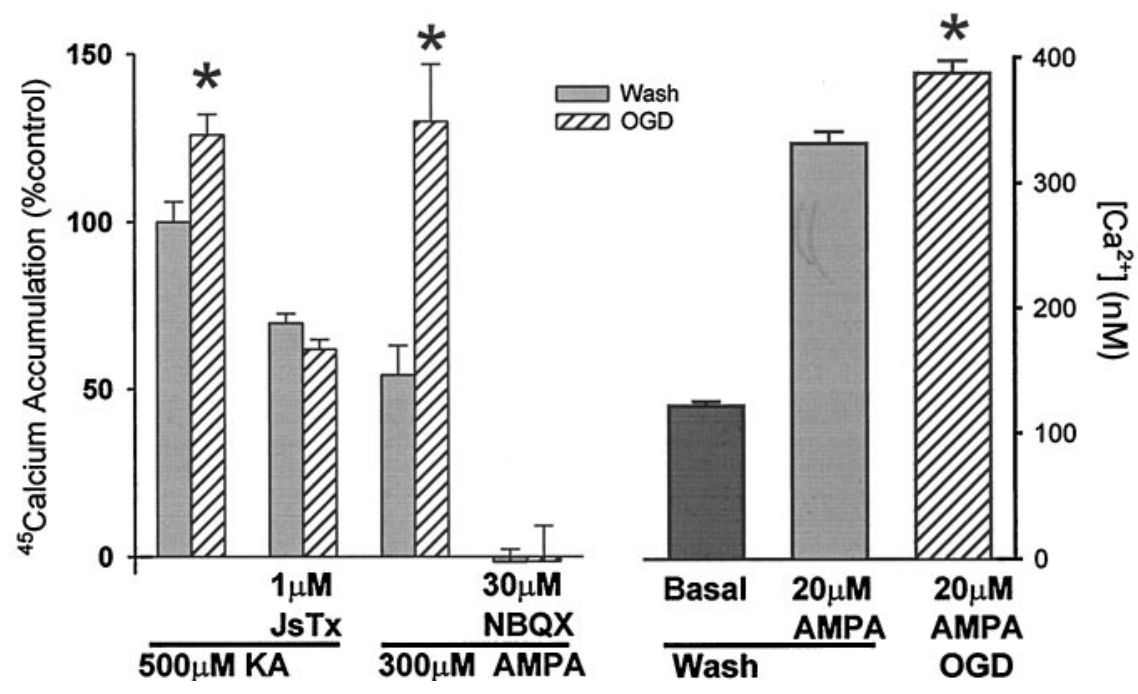

Figure 5. Cultures exposed to sublethal oxygen-glucose deprivation (OGD) exhibit increased AMPA/ kainate-activated ${ }^{45} \mathrm{Ca}^{2+}$ accumulation and AMPAactivated $\Delta\left[\mathrm{Ca}^{2+}\right]_{\mathrm{i}}$ in neurons. $A,{ }^{45} \mathrm{Ca}^{2+}$ accumulation during a $5 \mathrm{~min}$ exposure to $500 \mu \mathrm{M}$ kainate or $300 \mu \mathrm{M}$ AMPA in either sham-washed controls or cultures exposed to sublethal OGD $24 \mathrm{hr}$ earlier (mean \pm SEM; $n=8-14$ cultures). Both kainate- and AMPA-activated ${ }^{45} \mathrm{Ca}^{2+}$ accumulation were potentiated by sublethal OGD, and the kainate-induced potentiation was eliminated by $1 \mu \mathrm{M}$ Joro spider toxin. $B$ Sublethal OGD also potentiated the increase in $\left[\mathrm{Ca}^{2+}\right]_{\mathrm{i}}$ evoked by a $15 \mathrm{sec}$ exposure to $20 \mu \mathrm{M}$ AMPA (mean $\pm \mathrm{SEM} ; n=122-137$ cells from 4 separate experiments). Basal $\left[\mathrm{Ca}^{2+}\right]_{\mathrm{i}}$ levels in neurons exposed to sublethal OGD were not different from those exposed to sham wash (data not shown). Asterisks indicate difference from respective sham-washed control at $p<0.05$, using two-tailed Student's $t$ test.

This increase in kainate-stimulated ${ }^{45} \mathrm{Ca}^{2+}$ accumulation was sensitive to Joro spider toxin $(1 \mu \mathrm{M})$, a selective blocker of AMPA receptors containing only subunits unedited at the $\mathrm{Q} / \mathrm{R}$ site (Blaschke et al., 1993) (Fig. 5A).

In addition to increasing AMPA or kainate-activated ${ }^{45} \mathrm{Ca}^{2+}$ accumulation, oxygen-glucose deprivation conditioning also mildly elevated the peak increase in neuronal $\left[\mathrm{Ca}^{2+}\right]_{\mathrm{i}}(\mathrm{Yu}$ et al., 1997) evoked by a $15 \mathrm{sec}$ pulse of $20 \mu \mathrm{M}$ AMPA, without changing basal $\left[\mathrm{Ca}^{2+}\right]_{\mathrm{i}}$ levels (Fig. $5 B$ ). This increase in neuronal AMPAactivated $\Delta\left[\mathrm{Ca}^{2+}\right]_{\mathrm{i}}$ suggests that the observed increase in total ${ }^{45} \mathrm{Ca}^{2+}$ accumulation was attributable, at least in part, to an increase in neuronal $\mathrm{Ca}^{2+}$ influx.

\section{Excitotoxicity assays}

Cultures containing both neurons and astrocytes were sham washed or exposed to conditioning oxygen-glucose deprivation as described above, and then exposed to kainate for $24 \mathrm{hr}$, NMDA for $5 \mathrm{~min}$, or oxygen-glucose deprivation for $100 \mathrm{~min}$. Oxygenglucose deprivation conditioned cultures were more susceptible than sham-washed cultures to $30 \mu \mathrm{M}$ kainate toxicity (Table 3). Interestingly, this potentiation of kainate toxicity did not generalize to death induced by exposure to NMDA or lethal oxygenglucose deprivation.

\section{DISCUSSION}

The main finding of the present study is that a conditioning exposure to sublethal oxygen-glucose deprivation shifted AMPA receptor subunit expression in individual cultured hippocampal neurons by increasing GluR-D (flop) expression, resulting in an increased abundance of GluR-D mRNA relative to GluR-A and GluR-B mRNA. This result was obtained by using an RT-PCR procedure that was optimized for the quantitative relative detection of AMPA receptor subunits. Supporting the idea that this change in AMPA receptor expression translated into functionally important changes in AMPA receptor behavior, we demonstrated that the same conditioning exposure also increased net (as well as Joro spider toxin-sensitive) AMPA or kainate-stimulated ${ }^{45} \mathrm{Ca}^{2+}$ accumulation in the hippocampal cells, and AMPA-stimulated $\left[\mathrm{Ca}^{2+}\right]_{\mathrm{i}}$ responses, and it selectively increased vulnerability to
Table 3. Sublethal oxygen-glucose deprivation (OGD) increases kainate-mediated excitotoxicity

\begin{tabular}{lcll} 
& \multicolumn{2}{c}{ Cell death $(\%)$} & \\
\cline { 2 - 3 } Condition & Sham wash & OGD & $p$ \\
\hline Blank & $0 \pm 1.8$ & & \\
$30 \mu \mathrm{M}$ kainate & $38.4 \pm 2.1^{a}$ & $58.8 \pm 4.4^{a, b}$ & 0.0002 \\
$150 \mu \mathrm{M}$ NMDA & $44.5 \pm 4.1^{a}$ & $36.4 \pm 3.1^{a}$ & 0.114 \\
100 min OGD & $59.5 \pm 3.4^{a}$ & $44.7 \pm 1.4^{a}$ & 0.007 \\
\hline
\end{tabular}

Kainate or NMDA was applied at the indicated concentrations for $24 \mathrm{hr}$ to cultures subjected to a 30 min sublethal oxygen-glucose deprivation or sham wash $24 \mathrm{hr}$ before excitotoxin exposure. Toxin-specific cell death was estimated by measuring LDH efflux into the bathing medium at the end of the excitotoxin exposure, subtracting LDH efflux from sham-washed cultures, and scaling to the mean LDH value corresponding to near-complete neuronal death $(100 \%$, induced by $24 \mathrm{hr}$ exposure to $500 \mu \mathrm{M}$ NMDA) in sister cultures. Sublethal oxygen-glucose deprivation does not affect LDH release induced by $24 \mathrm{hr}$ exposure to $500 \mu \mathrm{M}$ NMDA. $n=12$ cultures per condition, mean \pm SEM.

${ }^{a}$ Difference from cell death in cultures exposed to media alone (Blank); $p<0.05$ using one-way ANOVA with Bonferroni correction.

${ }^{b}$ Difference from cell death in corresponding sham wash-conditioned cultures; $p=0.0002$, using one-way ANOVA.

kainate-induced neuronal death. It is thus parsimonious to attribute the observed changes in AMPA receptor function to the observed changes in AMPA receptor subunit gene expression. Only a modest transient change in overall protein synthesis was produced by the conditioning insult, arguing against the alternative possibility that increased AMPA receptor $\mathrm{Ca}^{2+}$ influx was caused by differential receptor subunit degradation and turnover during a period of global protein synthesis inhibition. Furthermore, we have shown previously that inhibition of global protein synthesis with cycloheximide did not increase, but rather reduced, vulnerability to kainate-induced neuronal death (Lobner and Choi, 1996).

It is noteworthy that the oxygen-glucose deprivation conditioning-evoked increase in vulnerability to kainate-induced hippocampal neuronal death was selective and did not extend to NMDA-induced death or oxygen-glucose deprivation-induced death. Indeed, conditioning mildly decreased total neuronal death 
after the latter insult, a finding consistent with in vivo data suggesting that exposure to sublethal ischemia can reduce brain vulnerability to subsequent, more severe ischemic insults (Kitagawa et al., 1990; Kirino et al., 1991), and with similar conditioning benefits observed previously in cortical cell cultures (Grabb and Choi, 1995). There is no incompatibility between the observation that conditioning increased neuronal vulnerability to death specifically mediated by AMPA/kainate receptors and the observation that the same conditioning reduced total neuronal vulnerability to death induced by oxygen-glucose deprivation. Presumably, mechanisms different from changes in AMPA receptor expression-for example, the enhancement of free radical scavenging ability or induction of neuroprotective genes (Ohtsuki et al., 1993, 1996) may account for the beneficial effects of conditioning against oxygen-glucose deprivation injury.

\section{Increased expression of $\mathrm{Ca}^{2+}$-permeable AMPA receptors: contribution of changes in expression of GluR-D versus GluR-B}

The finding by Pellegrini-Giampietro et al. (1992, 1994) that transient global ischemia produced a preferential downregulation in hippocampal CA1 neuronal GluR-B expression relative to other AMPA receptor subunits has been supported by observations in animal seizure models (Friedman et al., 1994; Prince et al., 1995). The ischemia-induced decrease in GluR-B expression does not require cell death, because it is not blocked by posttreatment with protective concentrations of NBQX (PellegriniGiampietro et al., 1994) but may be blocked by highly neuroprotective pretreatments (Heurteaux et al., 1995). Furthermore, studies by Tsubokawa et al. (1995a,b) and Gorter et al. (1997) have suggested that neurons exposed to conditioning ischemia exhibit larger AMPA receptor-mediated currents sensitive to Joro spider toxin or exhibit larger increases in AMPA receptormediated $\mathrm{Ca}^{2+}$ influx. Other studies, however, examining expression of multiple AMPA receptor subunits after ischemia (Diemer et al., 1994; Frank et al., 1995) or seizures (Condorelli et al., 1994; Gold et al., 1996) did not observe preferential decreases in GluR-B expression.

In the present study, no change in GluR-B expression levels was seen in mRNA extracted from cultures of neurons and glia exposed to preconditioning oxygen-glucose deprivation, or from the total population of individually sampled neurons. However, there was a trend toward reduction in GluR-B mRNA relative abundance that was washed out by the unusual behavior of four cells that had unusually low $(<4 \%)$ levels of GluR-D and relatively high levels of GluR-B after oxygen-glucose deprivation (Fig. 3). In light of the possibility that these four cells represented a distinctive subpopulation, we performed a post hoc analysis of the remaining 19 cells, which exhibited high levels of GluR-D expression after conditioning. In this majority subpopulation, GluR-B expression levels were lower than in sham-washed controls $(34.4 \pm 5.0 \%$ vs $23.1 \pm 2.5 \% ; p=0.047$ using two-tailed Student's $t$ test). Support for the validity of this analysis was provided by the finding of increased Joro spider toxin-sensitive kainate-induced ${ }^{45} \mathrm{Ca}^{2+}$ accumulation (see below). Conditioned cells with high GluR-D did not differ in the relative expression levels of GluR-A $(35.5 \pm 4.5 \%$ vs $26.5 \pm 3.7 \% ; p=0.130$ using two-tailed Student's $t$ test) or GluR-C (18.2 $\pm 3.8 \%$ vs $17.8 \pm$ $3.6 \% ; p=0.939$ using two-tailed Student's $t$ test) compared with sham-washed controls.

The possibility of a reciprocal relationship between GluR-B and GluR-D expression in single neurons fits with three earlier observations: (1) in Bergmann glial cells, where GluR-A and GluR-D mRNA are expressed without GluR-B or GluR-C mRNA (Keinanen et al., 1990; Monyer et al., 1991); (2) in cultured neocortical neurons, where GluR-D immunoreactivity colocalized with GluR-A but not with GluR-B/C immunoreactivity (Yin et al., 1994); and (3) in cultured GABAergic type II neurons from hippocampus, which express GluR-A and GluR-D, but not GluR-B, mRNA (Bochet et al., 1994). Furthermore, relative GluR-B and GluR-D mRNA abundance suggested an inverse relationship across several different neuronal types (Geiger et al., 1995). It is conceivable that GluR-B and GluR-D are regulated in a way to make co-expression infrequent.

Recently, mice deficient in GluR-B were generated and shown to have enhanced kainate-induced calcium currents (Jia et al., 1996). These mice showed mild behavioral deficits but could attain normal size and appearance. Although this important experiment indicates that a remarkably normal nervous system can develop lacking GluR-B, it is not incompatible with the idea that acute downregulation of GluR-B in the adult animal could lead to a deleterious increase in AMPA receptor-mediated excitotoxicity. It is plausible that the absence of GluR-B during development might induce compensatory changes, such as enhanced calcium buffering or extrusion. Mice expressing editingdeficient GluR-B did develop seizures and early death (Brusa et al., 1995), perhaps indicating that it is more difficult for the developing animal to adjust for aberrant GluR-B subunits than for complete absence of GluR-B.

What is the significance of the relative increase in neuronal GluR-D expression induced by oxygen-glucose deprivation? First, this increase, in the subset of neurons in which it occurred, could contribute to lowering the relative abundance of GluR-B, a change that might increase the probability that AMPA receptors will form lacking a GluR-B subunit and thus gate channels with enhanced $\mathrm{Ca}^{2+}$ permeability. Such a lowering of GluR-B relative abundance could reflect either an absolute decrease in GluR-B mRNA levels or an absolute increase in other AMPA receptor subunit levels (or both). Second, increasing GluR-D representation in native AMPA receptors per se might alter resultant receptor or channel characteristics and produce, for example, faster channel desensitization (Geiger et al., 1995).

\section{Flip/flop alternative splicing}

Flip/flop analysis of GluR-D showed that the conditioninginduced increase in relative GluR-D was caused by a selective increase in GluR-D flop (Fig. 4). In heterologous expression systems, flop isoforms generally produce lower peak currents and smaller nondesensitizing currents at the whole-cell level (Sommer et al., 1990; Monyer et al., 1991; Mosbacher et al., 1994) and smaller unitary conductances at the single channel level (Swanson et al., 1997).

\section{RNA editing}

RNA editing of glutamate receptor subunits seems to be a highly regulated phenomenon and another mechanism by which a cell can alter AMPA receptor calcium permeability (Q/R site) (Burnashev et al., 1992) or recovery from desensitization kinetics ( $\mathrm{R} / \mathrm{G}$ site) (Lomeli et al., 1994). In studies using adult human brain, the GluR-B Q/R site was $>99 \%$ edited in cortex but was edited to a lesser degree in striatum or substantia nigra (Nutt and Kamboj, 1994), and decreased GluR-B Q/R site editing was observed in Alzheimer's disease, Huntington's disease, or schizophrenia patients (Akbarian et al., 1995). We did not see unedited 
GluR-B (Q) in either sham-washed or conditioned cultures, to the limits of assay detection (3\%). This result is consistent with several rodent in vivo studies in which GluR-B was fully edited at the $\mathrm{Q} / \mathrm{R}$ site in several different brain regions (Geiger et al., 1995), during different developmental ages (Burnashev et al., 1992), or after transient ischemia (Paschen et al., 1996).

\section{${ }^{45} \mathrm{Ca}^{2+}$ accumulation and $\Delta\left[\mathrm{Ca}^{2+}\right]_{\mathrm{i}}$}

Sublethal oxygen-glucose deprivation caused an increase in both AMPA- and kainate-activated ${ }^{45} \mathrm{Ca}^{2+}$ accumulation, as well as AMPA-activated $\Delta\left[\mathrm{Ca}^{2+}\right]_{\mathrm{i}}$. Joro spider toxin $(1 \mu \mathrm{M})$ completely blocked the enhanced kainate-activated ${ }^{45} \mathrm{Ca}^{2+}$ accumulation in oxygen-glucose deprivation conditioned cultures, thus implicating AMPA receptors lacking GluR-B in the phenomenon. We also noted, however, that $1 \mu \mathrm{M}$ Joro spider toxin only blocked $\sim 30 \%$ of the kainate-activated ${ }^{45} \mathrm{Ca}^{2+}$ accumulation in shamwashed cultures. In addition, kainate-stimulated ${ }^{45} \mathrm{Ca}^{2+}$ accumulation was only slightly blocked $(<20 \%)$ by $10 \mu \mathrm{M} \mathrm{Gd}{ }^{3+}$, a nonselective $\mathrm{Ca}^{2+}$ channel blocker (Yang and Sachs, 1989; Biagi and Enyeart, 1990) that completely blocks $60 \mathrm{~mm} \mathrm{~K}{ }^{+}$-activated $\mathrm{Ca}^{2+}$ accumulation (data not shown). These data suggest that Joro spider toxin-insensitive kainate-stimulated ${ }^{45} \mathrm{Ca}^{2+}$ accumulation may partly result from permeation through standard AMPA receptors containing edited GluR-B subunits at the $Q / R$ site. Fractional calcium currents through recombinant AMPA receptors containing an edited GluR-B subunit were still detectable, with $\sim 15 \%$ of the current through AMPA receptors expressing unedited GluR-B subunits (Burnashev et al., 1995).

\section{Implications for the ischemic brain}

Why should the brain shift to the generation of $\mathrm{Ca}^{2+}$-permeable AMPA receptors after oxygen-glucose deprivation insults? Possibly, increased GluR-D flop changes receptor behavior in other favorable ways, such as increasing desensitization and thus limiting post-ischemic overexcitation. Alternatively, even if increased $\mathrm{Ca}^{2+}$ influx does occur through conditioned AMPA receptors, it may inhibit potentially larger and more dangerous $\mathrm{Ca}^{2+}$ influx mediated by NMDA receptors (Medina et al., 1994; Kyrozis et al., 1995).

In any case, the demonstrated net increase in vulnerability to kainate-induced death is plausibly linked to the pathogenesis of the delayed hippocampal CA1 neuronal death that occurs several days after a global ischemic insult. This delayed selective neuronal death is reduced by postischemic application of AMPA receptor antagonists (Buchan et al., 1991b; Nellgard and Wieloch, 1992) or concurrent application of protein synthesis inhibitors (Goto et al., 1990; Shigeno et al., 1990). These observations are consistent with the hypothesis that synthesis of new $\mathrm{Ca}^{2+}$. permeable AMPA receptors and consequent heightened vulnerability to AMPA receptor-mediated excitotoxic death is a key underlying event in hippocampal CA1 neuronal death after global ischemia.

Furthermore, evidence that $\mathrm{Ca}^{2+}$-permeable AMPA receptors are also $\mathrm{Zn}^{2+}$ permeable (Yin and Weiss, 1995; Sensi et al., 1997) suggests that the same shift in glutamate receptor expression would increase toxic zinc accumulation, another event that may contribute importantly to delayed selective neuronal death after transient global ischemia (Koh et al., 1996).

\section{REFERENCES}

Aizenman E, Lipton SA, Loring RH (1989) Selective modulation of NMDA responses by reduction and oxidation. Neuron 2:1257-1263.
Albers GW, Goldberg MP, Choi DW (1989) NMDA antagonists: ready for clinical trial in brain ischemia? Ann Neurol 25:398-403.

Akbarian S, Smith MA, Jones EG (1995) Editing for an AMPA receptor subunit RNA in prefrontal cortex and striatum in Alzheimer's disease, Huntington's disease, and schizophrenia. Brain Res 699:297-304.

Biagi BA, Enyeart JJ (1990) Gadolinium blocks low- and high-threshold calcium currents in pituitary cells. Am J Physiol 259:C515-520.

Blaschke M, Keller B, Rivosecchi R, Hollmann M, Heinemann S, Konnerth A (1993) A single amino acid determines the subunit specific spider toxin block of $\alpha$-amino-3-hydroxy-5-methyl-4-propionate/kainate receptor channels. Proc Natl Acad Sci USA 90:6528-6532.

Bochet P, Audinat E, Lambolez B, Crepel F, Rossier J, Iino M, Tsuzuki K, Ozawa S (1994) Subunit composition at the single-cell level explains functional properties of a glutamate-gated channel. Neuron 12:383-388.

Brusa R, Zimmermann F, Koh DS, Feldmeyer D, Gass P, Seeburg PH, Sprengel R (1995) Early-onset epilepsy and postnatal lethality associated with an editing-deficient GluR-B allele in mice. Science 270:1677-1680.

Buchan AM (1990) Do NMDA antagonists protect against cerebral ischemia: are clinical trials warranted? Cereb Brain Metab Rev 2:1-26.

Buchan AM, Li H, Cho SH, Pulsinelli WA (1991a) Blockade of the AMPA receptor prevents CA1 hippocampal injury following severe but transient forebrain ischemia in adult rats. Neurosci Lett 132:255-258.

Buchan AM, Xue D, Huang ZG, Smith KH, Lesiuk H (1991b) Delayed AMPA receptor blockade reduces cerebral infarction induced by focal ischemia. NeuroReport 2:473-476.

Burnashev N (1996) Calcium permeability of glutamate-gated channels in the central nervous system. Curr Opin Neurobiol 6:311-317.

Burnashev N, Monyer H, Seeburg PH, Sakmann B (1992) Divalent ion permeability of AMPA receptor channels is dominated by the edited form of a single subunit. Neuron 8:189-198.

Burnashev N, Zhou Z, Neher E, Sakmann B (1995) Fractional calcium currents through recombinant GluR channels of the NMDA, AMPA, and kainate receptor subtypes. J Physiol (Lond) 485:403-418.

Choi DW (1985) Glutamate neurotoxicity in cortical cell culture is calcium dependent. Neurosci Lett 58:293-297.

Choi DW (1992) Excitotoxic cell death. J Neurobiol 23:1261-1276.

Choi DW, Rothman SM (1990) The role of glutamate neurotoxicity in hypoxic-ischemic neuronal death. Annu Rev Neurosci 13:171-182.

Condorelli DF, Belluardo N, Mudo G, Dell'Albani P, Jiang X, GiuffridaStella AM (1994) Changes in gene expression of AMPA-selective glutamate receptor subunits induced by status epilepticus in rat brain. Neurochem Int 25:367-376.

Dichter MA (1978) Rat cortical neurons in cell culture: culture methods cell morphology electrophysiology and synapse formation. Brain Res 149:279-293.

Diemer NH, Rosdahl D, Seitzberg D, Neilsen M, Christensen T, Balchen T, Bruhn T, Jorgensen MB, Johansen FF (1994) Changes in AMPAand mGluR mRNA after cerebral ischemia in the rat. In: Pharmacology of cerebral ischemia (Kriegelstein J, Oberpichker-Schwenk H, eds), pp 119-129. Stuttgart: Medpharm Scientific.

Eberwine J, Yeh H, Miyashiro K, Cao Y, Nair S, Finnel R, Zettel M, Coleman P (1992) Analysis of gene expression in single live neurons. Proc Natl Acad Sci USA 89:3010-3014.

Egebjerg J, Kukekov V, Heinemann SF (1994) Intron sequence directs RNA editing of the glutamate receptor GluR2 coding sequence. Proc Natl Acad Sci USA 91:10270-10274.

Flint AC, Maisch US, Weishaupt JH, Kriegstein AR, Monyer H (1997) NR2A subunit expression shortens NMDA receptor synaptic currents in developing neocortex. J Neurosci 17:2469-2476.

Frank L, Diemer NH, Kaiser F, Sheardown M, Rasmussen JS, Kristensen P (1995) Unchanged balance between levels of mRNA encoding AMPA glutamate receptor subtypes following global cerebral ischemia in the rat. Acta Neurol Scand 92:337-343.

Friedman LK, Pellegrini-Giampietro DE, Sperber EF, Bennett MVL, Moshe SL, Zukin RS (1994) Kainate-induced status epilepticus alters glutamate and $\mathrm{GABA}_{\mathrm{A}}$ receptor gene expression in adult rat hippocampus: an in situ hybridization study. J Neurosci 14:2697-2707.

Geiger JRP, Melcher T, Koh D-S, Sakmann B, Seeburg PH, Jonas P, Monyer H (1995) Relative abundance of subunit mRNAs determines gating and $\mathrm{Ca}^{2+}$ permeability of AMPA receptors in principal neurons and interneurons in rat CNS. Neuron 15:193-204.

Giffard RG, Moyner H, Christine CW, Choi DW (1990) Acidosis reduces NMDA receptor activation glutamate neurotoxicity and oxygen- 
glucose deprivation neuronal injury in cortical cultures. Brain Res 506:339-342.

Gold SJ, Hennegriff M, Lynch G, Gall CM (1996) Relative concentrations and seizure-induced changes in mRNAs encoding three AMPA receptor subunits in hippocampus and cortex. J Comp Neurol 365:541-555.

Goldberg MP, Choi DW (1993) Combined oxygen and glucose deprivation in cortical cell culture: calcium-dependent and calciumindependent mechanisms of neuronal injury. J Neurosci 13:3510-3524.

Gorter JA, Petrozzino JJ, Aronica EM, Rosenbaum DM, Opitz T, Bennett MVL, Connor JA, Zukin RS (1997) Global ischemia induces downregulation of Glur2 mRNA and increases AMPA receptormediated $\mathrm{Ca}^{2+}$ influx in hippocampal CA1 neurons of gerbil. J Neurosci 17:6179-6188.

Goto K, Ishige A, Sekiguchi K, Iizuka S, Sugimoto A, Yuzurihara M, Aburada M, Hosoya E, Kogure K (1990) Effects of cyclohexamide on delayed neuronal death in rat hippocampus. Brain Res 534:299-302.

Grabb MC, Choi DW (1995) "Ischemic tolerance" in cortical cell culture. Soc Neurosci Abstr 21:1729.

Grynkiewicz G, Poenie M, Tsien R (1985) A new generation of $\mathrm{Ca}^{2+}$ indicators with greatly improved fluorescence properties. J Biol Chem 260:3440-3450.

Hartley DM, Kurth MC, Bjerkness L, Weiss JH, Choi DW (1993) Glutamate receptor-induced ${ }^{45} \mathrm{Ca}^{2+}$ accumulation in cortical cell culture correlates with subsequent neuronal degeneration. J Neurosci 13:1993-2000.

Hellman B (1978) Calcium and pancreatic b-cell function. 3. Validity of the La-wash technique for discriminating between superficial and intracellular ${ }^{45} \mathrm{Ca}$. Biochim Biophys Acta 540:534-542.

Heurteaux C, Lauritzen I, Widmann C, Lazdunski M (1995) Essential role of adenosine A1 receptors and ATP-sensitive $\mathrm{K}^{+}$channels in cerebral ischemic preconditioning. Proc Natl Acad Sci USA 92:4666-4670.

Holzwarth JA, Gibbons SJ, Brorson JR, Philipson LH, Miller RJ (1994) Glutamate receptor agonists stimulate diverse calcium responses in different types of cultured rat cortical glial cells. J Neurosci 14:1879-1891.

Hume RI, Dingledine R, Heinemann SF (1991) Identification of a site in glutamate receptor subunits that controls calcium permeability. Science 253:1028-1031.

Jia ZP, Agopyan N, Miu P, Xiong ZG, Henderson J, Gerlai R, Taverna FA, Velumian A, MacDonald J, Carlen P, Abramownewerly W, Roder J (1996) Enhanced LTP in mice deficient in the AMPA receptor GluR2. Neuron 17:945-956.

Jonas P, Racca C, Sakmann B, Seeburg PH, Monyer H (1994) Differences in $\mathrm{Ca}^{2+}$ permeability of AMPA-type glutamate receptor channels in neocortical neurons caused by differential GluR-B subunit expression. Neuron 12:1281-1289.

Keinanen K, Wisden W, Sommer B, Werner P, Herb A, Verdoorn TA, Sakmann B, Seeburg PH (1990) A family of AMPA-selective glutamate receptors. Science 249:556-560.

Kirino T, Sano K (1984) Fine structural nature of delayed neuronal death following ischemia in the gerbil hippocampus. Acta Neuropathol (Berl) 62:209-218.

Kirino T, Tsujita Y, Tamura A (1991) Induced tolerance to ischemia in gerbil hippocampal neurons. J Cereb Blood Flow Metab 11:299-307.

Kitagawa K, Matsumoto M, Tagaya M, Hata R, Ueda H, Niiobe M, Handa N, Fukunaga R, Kimura K, Mikoshiba K, Kamada T (1990) "Ischemic tolerance" phenomenon found in the brain. Brain Res 528:21-24.

Kleihues P, Hossmann KA (1971) Protein synthesis in the cat brain after prolonged cerebral ischemia. Brain Res 35:409-418.

Koh JY, Choi DW (1987) Quantitative determination of glutamate mediated cortical neuronal injury in cell culture by lactate dehydrogenase efflux assay. J Neurosci Methods 20:83-90.

Koh JY, Suh SW, Gwag BJ, He YY, Hsu CY, Choi DW (1996) The role of zinc in selective neuronal death after transient global cerebral ischemia. Science 272:1013-1016.

Kyrozis A, Goldstein PA, Heath MJ, MacDermott AB (1995) Calcium entry through a subpopulation of AMPA receptors desensitized neighbouring NMDA receptors in rat dorsal horn neurons. J Physiol (Lond) 485:373-381.

Lambolez B, Audinat E, Bochet P, Crepel F, Rossier J (1992) AMPA receptor subunits expressed by single Purkinje cells. Neuron 9:247-258.

Lobner D, Choi DW (1996) Preincubation with protein synthesis inhib- itors protects cortical neurons against oxygen-glucose deprivationinduced death. Neuroscience 72:335-341.

Lomeli H, Mosbacher J, Melcher T, Hoger T, Geiger JRP, Kuner T, Monyer H, Higuchi M, Bach A, Seeburg PH (1994) Control of kinetic properties of AMPA receptor channels by nuclear RNA editing. Science 266:1709-1713.

Maas S, Melcher T, Herb A, Seeburg PH, Keller W, Krause S, Higuchi M, O'Connell MA (1996) Structural requirements for RNA editing in glutamate receptor pre-mRNAs by recombinant double-stranded RNA adenosine deaminase. J Biol Chem 271:12221-12226.

MacDermott AB, Mayer ML, Westbrook GL, Smith SJ, Barker JL (1986) NMDA-receptor activation increases cytoplasmic calcium concentration in cultured spinal cord neurones. Nature 321:519-522.

Medina I, Filippova N, Barbin G, Ben-Ari Y, Bregestovski P (1994) Kainate-induced inactivation of NMDA currents via an elevation of intracellular $\mathrm{Ca}^{2+}$ in hippocampal neurons. J Neurophysiol 72:456-465.

Melcher T, Maas S, Herb A, Sprengel R, Seeburg PH, Higuchi M (1996) A mammalian RNA editing enzyme. Nature 379:460-464.

Meldrum BS (1985) Possible therapeutic applications of antagonists of excitatory amino acid neurotransmitters. Clin Sci 68:113-122.

Monyer H, Jonas P (1995) Polymerase chain reaction analysis of ion channel expression in single neurons of brain slices. In: Single-channel recording (Sakmann B, Neher E, eds). pp 357-373. New York: Plenum.

Monyer H, Seeburg PH, Wisden W (1991) Glutamate-operated channels: developmentally early and mature forms arise by alternative splicing. Neuron 6:799-810.

Mosbacher J, Schoepfer R, Monyer H, Burnashev N, Seeburg PH, Ruppersberg JP (1994) A molecular determinant for submillisecond desensitization in glutamate receptors. Science 266:1059-1062.

Nellgard B, Wieloch T (1992) Postischemic blockade of AMPA but not NMDA receptors mitigates neuronal damage in the rat brain following transient severe cerebral ischemia. J Cereb Blood Flow Metab 12:2-11.

Nutt SL, Kamboj RK (1994) Differential RNA editing efficiency of AMPA receptor subunit GluR-2 in human brain. NeuroReport 5:1679-1683.

Ohtsuki T, Matsumoto M, Suzuki K, Taniguchi N, Kamada T (1993) Effect of transient forebrain ischemia on superoxide dismutases in gerbil hippocampus. Brain Res 620:305-309.

Ohtsuki T, Ruetzler CA, Tasaki K, Hallenbeck JM (1996) Interleukin-1 mediates induction of tolerance to global ischemia in gerbil hippocampal CA1 neurons. J Cereb Blood Flow Metab 16:1137-1142.

Paschen W, Schmitt J, Uto A (1996) RNA editing of glutamate subunits GluR2, GluR5, and GluR6 in transient cerebral ischemia in the rat. J Cereb Blood Flow Metab 16:548-556.

Pellegrini-Giampetro DE, Zukin RS, Bennett MVL, Cho S, Pulsinelli WA (1992) Switch in glutamate receptor subunit gene expression in CA1 subfield of hippocampus following global ischemia in rats. Proc Natl Acad Sci USA 89:10499-10503.

Pellegrini-Giampetro DE, Pulsinelli WA, Zukin RS (1994) NMDA and non-NMDA receptor gene expression following global brain ischemia in rats: effect of NMDA and non-NMDA receptor antagonists. J Neurochem 62:1067-1073.

Peters S, Koh J, Choi DW (1987) Zinc selectively blocks the action of $N$-methyl-D-aspartate on cortical neurons. Science 236:589-593.

Prince HK, Conn PJ, Blackstone CD, Huganir RL, Levey AI (1995) Down-regulation of AMPA receptor subunit GluR2 in amygdaloid kindling. J Neurochem 64:462-465.

Puchalski RB, Louis J-C, Brose N, Traynelis SF, Egebjerg J, Kukekov V, Lin F, Moran T, Morrison JH, Heinemann SF (1994) Selective RNA editing and subunit assembly of native glutamate receptors. Neuron 13:131-147.

Rose K, Goldberg MP, Choi DW (1993) Cytotoxicity in murine cortical cell culture. In: In vitro biological systems (Tyson CA, Frazier JM, eds), pp 46-60. San Diego: Academic.

Seeburg PH (1996) The role of RNA editing in controlling glutamate receptor channel properties. J Neurochem 66:1-5.

Sensi SL, Canzoniero LMT, Yu SP, Ying H, Koh JY, Kerchner GA, Choi DW (1997) Measuremant of intracellular free zinc in living cortical neurons: routes of entry. J Neurosci 17:9554-9564.

Sheardown MJ, Nielsen EO, Hansen AJ, Jacobsen P, Honore T (1990) 2,3-Dihydroxy-6-nitro-7-sulfamoyl-benzo(F)quinoxaline: a neuroprotectant for cerebral ischemia. Science 247:571-574.

Shigeno T, Yamasaki Y, Kato G, Kusaka K, Mima T, Takakura K, 
Graham DI, Furukawa S (1990) Reduction of delayed neuronal death by inhibition of protein synthesis. Neurosci Lett 120:117-119.

Sommer B, Keinanen K, Verdoorn TA, Wisden W, Burnashev N, Herb A, Kohler M, Takagi T, Sakmann B, Seeburg PH (1990) Flip and flop: a cell-specific functional switch in glutamate-operated channels of the CNS. Science 249:1580-1585.

Swanson GT, Kamboj SK, Cull-Candy SG (1997) Single-channel properties of recombinant AMPA receptors depend on RNA editing splice variation and subunit composition. J Neurosci 17:58-69.

Tang CM, Dichter M, Morad M (1990) Modulation of the $N$-methyl-Daspartate channel by extracellular $\mathrm{H}^{+}$. Proc Natl Acad Sci USA 87:6445-6449.

Thilmann R, Xie Y, Kleihues P, Kiessling M (1986) Persistent inhibition of protein synthesis precedes delayed neuronal death in postischemic gerbil hippocampus. Acta Neuropathol (Berl) 71:88-93.

Tombaugh GC, Sapolsky RM (1990) Mild acidosis protects hippocampal neurons from injury induced by oxygen and glucose deprivation. Brain Res 506:343-345.

Tsubokawa HT, Oguro K, Robinson HPC, Masuzawa T, Kawai N (1995a) Single glutamate channels in CA1 pyramidal neurones after transient ischemia. NeuroReport 6:527-531.

Tsubokawa H, Oguro K, Masuzawa T, Nakaima T, Kawai N (1995b) Effects of a spider toxin and its analogue on glutamate-activated currents in the hippocampal CA1 neuron after ischemia. J Neurophysiol $74: 218-225$.
Weiss JH, Hartley DM, Koh J, Choi DW (1991) AMPA receptor activation potentiates zinc neurotoxicity. Neuron 10:43-49.

Westbrook GL, Mayer ML (1987) Micromolar concentrations of $\mathrm{Zn}^{2+}$ antagonize NMDA and GABA responses of hippocampal neurones. Nature 328:640-643.

Yang XC, Sachs F (1989) Block of stretch-activated ion channels in Xenopus oocytes by gadolinium and calcium ions. Science 243:1068-1071.

Yin HZ, Turetsky DM, Choi DW, Weiss JH (1994) Cortical neurons with $\mathrm{Ca}^{2+}$ permeable AMPA/kainate channels display distinct receptor immunoreactivity and are GABAergic. Neurobiol Dis 1:43-49.

Yin HZ, Weiss JH (1995) $\mathrm{Zn}^{2+}$ permeates $\mathrm{Ca}^{2+}$ permeable AMPA/ kainate channels and triggers selective neural injury. NeuroReport 6:2553-2556.

Yin HZ, Ha DH, Weiss JH (1996) $\mathrm{Zn}^{2+}$ permeation through $\mathrm{Ca}^{2+}$ permeable AMPA/kainate channels and selective neurodegeneration. Soc Neurosci Abstr 22:1278.

Ying HS, Weishaupt J, Grabb M, Canzoniero LMT, Sensi SL, Monyer H, Choi DW (1996) AMPA receptor expression in cultured rat hippocampal neurons following sublethal oxygen-glucose deprivation. Soc Neurosci Abstr 22:597.

Yu SP, Sensi SL, Canzoniero LMT, Buisson A, Choi DW (1997) Membrane-delimited modulation of NMDA currents by metabotropic glutamate receptor subtypes $1 / 5$ in cultured mouse cortical neurons. J Physiol (Lond) 499:721-732. 